\title{
A SURVEY OF POLISH CONSUMERS' VIEWS ON HEALTH AND NUTRITION CLAIMS MADE ON FOOD PACKAGING
}

\author{
BADANIE OPINII POLSKICH KONSUMENTÓW NA TEMAT OŚWIADCZEŃ ZDROWOTNYCH \\ I ŻYWIENIOWYCH NA OPAKOWANIACH PRODUKTÓW SPOŻYWCZYCH
}

\author{
Sylwia Majcher \\ Poznań University of Economics and Business, Poland \\ Al. Niepodległości 10, 61-875 Poznań \\ majcher.sylwia1@gmail.com 0 ORCID 0000-0003-0457-7301 \\ DOl: 10.2478/minib-2021-0018
}

\section{ABSTRACT}

Goal: To examine the impact of nutrition and health claims on Polish consumers' buying attitudes and intentions.

Design/methodology/approach: A questionnaire-based survey was conducted with a group of 200 Polish consumers using the CAWI method, selected by means of purposive, "snowball" sampling. The survey form consisted of 4 parts: A - evaluation of photos of sample products with nutrition claims, health claims, both type of claims, or no claims (control group); B - answering questions about food labelling and the use of nutrition claims; $\mathrm{C}$ - opining on health and nutrition claims presented as separate, non-product-specific messages.

Findings: The perception of the health and nutrition quality of products with health and nutrition claims was found to be strongly dependent on the consumer's attitude towards a given type of food. The presence of claims seems to have a neutral effect on the perception of the taste of products connoted with healthy eating, but a negative influence in the case of products considered unhealthy. Despite the great interest in the information contained in the labels of food products and healthy eating, Polish consumers still display only a slight degree of knowledge about such claims. At the same time, they seem to be skeptical of the reliability of the health and nutritional- related information on the packaging of food products, which is not correlated with their level of knowledge on the subject. The presence of claims is not decisive for consumers in terms of making purchasing decisions, and claims are less important to them than the use-by-date or the price of the product. Also, claims do not mean the product is perceived by consumers as less caloric.

Practical implications: In order to meet the expectations of modern consumers, food producers should consider placing both types of claims on labels, as well as undertaking other promotional activities that draw consumers' attention to the health and nutrition benefits of their products. Due to the fact that a good knowledge of and interest in healthy eating does not translate into a better understanding of nutrition claims, it is necessary to increase consumer awareness of food law. Due to consumer skepticism about health and nutritionalrelated information, food producers should ensure that the information on their product labels is as consistent as possible.

Originality and value: This is one of the few studies conducted among Polish food consumers that examine how the presence of health and nutrition claims on food labels affect perceptions and purchasing intentions regarding food products. 


\section{ABSTRAKT}

Cel: Celem tego badania jest poznanie czynników wpływających na podejmowanie decyzji o zakupie produktów z oświadczeniami zdrowotnymi i żywieniowymi przez polskich konsumentów.

Metodyka/Projekt badawczy: Badanie ankietowe zostało przeprowadzone na grupie 200 polskich konsumentów żywości za pomocą metody CAWI. Dobór próby był celowy i wykorzystujący efekt „kuli śnieżnej”. Formularz ankietowy składał się z 4 części: A — oceny zdjęć przykładowych produktów z oświadczeniami żywieniowymi i zdrowotnymi; B — udzielania odpowiedzi na pytania z zakresu etykietowania żywności i korzystania z oświadczeń żywieniowych; C — wyrażania opinii na temat oświadczeń zdrowotnych i żywieniowych przedstawionych jako odrębne, niewidniejące na konkretnym produkcie komunikaty.

Wnioski: Postrzeganie jakości zdrowotnej i odżywczej produktów opatrzonych oświadczeniami zdrowotnymi i żywieniowymi jest mocno zależne od postaw konsumenta wobec danego rodzaju żywności. Obecność oświadczeń wydaje się mieć neutralny wpływ na postrzeganie walorów smakowych produktów kojarzonych ze zdrowym odżywianiem, lecz negatywny w przypadku produktów uchodzących za niezdrowe. Pomimo dużego zainteresowania informacjami zawartymi na etykietach produktów żywnościowych i zdrowego odżywiania polscy konsumenci wciąż wykazują niską znajomość oświadczen. Jednocześnie wydają się oni być sceptycznie nastawieni do wiarygodności widniejących na opakowaniach komunikatów związanych ze zdrowiem i składnikami odżywczymi, co nie jest skorelowane z poziomem ich wiedzy na ten temat. Obecność oświadczeń nie jest decydująca dla konsumentów w kwestii podejmowania decyzji zakupowej, a oświadczenia są dla nich mniej istotne niż termin przydatności do spożycia czy cena produktu. Oświadczenia nie sprawiają także, że produkt jest postrzegany przez konsumentów jako mniej kaloryczny.

Praktyczne zalecenia: Chcąc spełnić oczekiwania wspótczesnych konsumentów producenci żywności powinni rozważyć umieszczanie na etykietach obu typów oświadczeń, a także podejmować inne działania promocyjnych, które zwrócą uwagę konsumentów na walory zdrowotne i odżywcze ich produktów. Z uwagi na fakt, iz wysoki poziom wiedzy i zainteresowania zdrowym odżywianiem nie przekładają się na lepszą znajomość oświadczeń konieczne jest podnoszenie świadomości konsumentów z zakresu prawa żywnościowego poprzez ułatwienie im dostępu do tego rodzaju wiedzy. Ze względu na panujący wśród konsumentów sceptycyzm wobec komunikatów związanych ze zdrowiem i wartością odżywczą producenci żywności powinni zadbać o jak największą zgodność informacji podawanych na etykietach swoich produktów.

Oryginalność badania: Jest to jedno z niewielu badań przeprowadzonych na polskich konsumentach żywności, które sprawdza jak oświadczenia zdrowotne i żywieniowe wpływają na postrzeganie oraz intencje zakupowe opatrzonych nimi produktów spożywczych.

Słowa kluczowe: Oświadczenia zdrowotne, oświadczenia żywieniowe, zachowania konsumentów, żywność

JEL: D180, I120, 1310, L700, M310

\section{Introduction}

The attitudes and behaviors of food consumers have changed significantly over the last decade or so, including a trend towards healthy eating and an interest in the influence of nutrients on general health, as well as in the prevention and treatment of existing diseases. As 
a consequence of these changes, foods with potentially beneficial effects on health and weight control have become more common (de Boer, 2021, pp.2).

The information on food packaging can encourage consumers to make healthier food choices, facilitate selection of portions adequate for their actual nutrition needs, and support their education in healthy eating. Unfortunately, reaping such benefits makes it difficult for them to navigate the food market, the quantity and variety of food products and the abundance of information contained on their labels. As a consequence, consumers focus their attention on simple messages (e.g. health and nutrition claims) that will help them find a product that stands out for its health or nutrition values. This approach may unfortunately lead them to make the wrong purchasing decisions. Claims are increasingly used to increase the purchase attractiveness of a product by food producers, who in many cases do not act honestly and mislead consumers (Davidović, et al., 2021, 1-2).

Ensuring that consumers can safely rely on the information on food packaging, as well as the highest quality and appropriateness of this information, is particularly important in the face of increasing obesity rates. By creating a friendly environment for consumers to make the right food choices, the epidemic of obesity and related diseases can be prevented and claims and other information on food packaging are a key element in this regard. For most consumers, they are the primary source of nutrition knowledge. Their role should be primarily to raise consumer awareness of the composition and properties of food products, and thus encourage their interest in healthy foods. In practice, however, buyers do not use them sufficiently due to difficulties in understanding them and the limited amount of time to make purchasing decisions (Oostenbach, Slits, Robinson \& Sacks, 2019, pp.2).

The impact of nutrition claims on consumer purchasing intentions and dietary choices has been the subject of research by many authors (e.g. Steinhauser, Janssen \& Hamm, 2019, pp. 4-14; Steinhauser \& Hamm, 2018, pp. 1-33; Lynam, McKevitt \& Gibney, 2011, pp. 2-6; Annunziata \& Mariani, 2019, pp. 3-13). However, there are few studies in which conclusions about attitudes and behaviors towards participants' statements are compared to their objectively verified knowledge about this form of marketing communication. There is also a dearth of studies that compare 
how consumers' perception of claims differs depending on whether they are placed on a product or are separate information.

Therefore, the main purposes of this paper are:

1. Identifying factors related to food consumers and producers that determine the effective influencing of claims on the perception of food products bearing them.

2. Finding factors that negatively affect the purchase intentions of products with claims.

3. Determining how claims affect the perception of products by consumers.

4. Seeing whether there is a correlation between consumers' knowledge of claims and their attitude towards them.

5. Understanding the determinants of effectively encouraging consumers to make healthier food choices through claims.

\section{The use of health and nutrition claims in the light of European food law}

Health claims describe or indicate the health-promoting effects of a given product or its ingredients. In turn, a nutrition claim is defined as any claim made on the label of a food product that relates to its nutritional value. The content of both health and nutrition claims must be comprehensible and transparent to consumers so that their interpretation will be truthful. One condition for making claims in accordance with European Food Law is that they must not imply that other foods are less healthy or less nutritious. It is also forbidden to use claims that imply that the consumption of a given product is necessary to cover the need for all essential nutrients. It is important that the regulations concerning claims also apply to symbols, trademarks or even product names, which should be supplemented by permitted statements (de Boer, 2021, p. 3). In addition, claims include not only health or nutrition messages placed on food packaging, but also those used in marketing campaigns and other promotional activities (OJEU, L 404, 30.12.2006, pp. 9).

Food law regulations regarding claims may vary depending on the laws and regulations issued in a given country. However, in the case of countries 
belonging to the European Union (EU), for example, they must meet certain standards and requirements. These conditions are primarily used to protect the health of consumers, as well as to minimize their being misled by the dishonest actions of producers (Szymura, 2012, pp. 1-3). The European Union has undertaken to achieve these objectives by issuing Regulation (EC) No 1924/2006 on nutrition and health claims (OJEU, L 404, 30.12.2006). However, in 2008 it issued Regulation (EC) No 107/2008 of the European Parliament and of the Council amending Regulation (EC) No 1924/2006 on nutrition and health claims made on foods as regards the implementing powers conferred on the Commission (OJEU L 39, 13.2.2008, p. 8-10). In Europe, in addition to the regulations contained in this regulation, validation of claims by the European Food Safety Authority (EFSA) is mandatory. Any claim that a given food producer wants to put on their product must indicate the nutrition or health properties supported by generally accepted, reliable scientific evidence (Szymecka-Wesołowska, 2011, pp. 21-22). Claims that pass EFSA verification are included in the publicly available list of approved claims. Currently, 30 nutrition claims listed in Regulation (EC) No. 1924/2006 are allowed on the food market. Any nutrition claim that a manufacturer wants to include on the packaging of their product must have the same meaning as any of the claims contained in the regulation and must meet the relevant nutrition criteria. For example, a product can be labeled "a source of protein" or a statement with the same wording may be used on its label only if at least $12 \%$ of its energy value comes from protein. In addition to indicating the source of the nutrient, nutrition claims can be formulated using the words (OJEU, L 404, 30.12.2006, pp. 9-25):

- Low/very low content/value...;

- High in...;

- Without, without additive, there is no, does not contain...;

- Contains...;

- With increased/reduced content...;

- Light;

- Natural/naturally...;

Moving on to health claims, 4 main types can be distinguished (de Boer, 2021, pp. 5): 
I. Functional claims based on generally accepted scientific evidence; II. Functional claims based on newly developed scientific insights;

III. Claims relating to the reduction of a risk factor in the development of the disease;

IV. Statements relating to the growth and development of children.

Although there are only 4 types of these claims, the number of claims that currently exist on the food market is 265. Examples of health claims include: Zinc helps to maintain a proper acid-base balance or magnesium contributes to the maintenance of proper energy metabolism (O. J. EU, L 136, 25.05.2012, pp. 4-40).

The conditions of use and the system for validating claims were checked during the European Commission's Regulatory Fitness and Performance Program (REFIT) from 2013 to 2020. One of the results of REFIT was that health and nutrition claims currently do not fully perform their role and new regulations are required to take into account the problems identified (de Boer, 2021, p.2). In addition, there are frequent cases of fraud involving use of statements that are inconsistent with the actual nutritional value or health properties of a given product (Lorenzoni, et al., 2019, pp. 3-12).

\section{Existing research on food consumers' understanding and use of claims}

In a study conducted on a group of 100 participants from five European countries - Germany, the Netherlands, Spain, Slovenia and the United Kingdom - it was examined whether and how food consumers understand selected health and nutrition claims. Out of these 100 participants, 51\% declared that they use statements quite often or very often, on a daily basis. Distinguishing between claims in terms of their types and meaning was not a problem for most participants in this study. The exceptions were statements with difficult vocabulary, such as, for example, one concerning homocysteine metabolism. Difficulties in understanding the statements also appeared when they referred to nutrients that are not very well known to participants or not very popular. Nutrition claims were rated more 
positively for affordability, but at the same time, the respondents believed that they should be supplemented with information on the health benefits of consuming the product. In addition, respondents expressed skepticism about nutrition claims indicating that the product is a meal replacement and those with reduced sugar and fat content. The statements were also considered by some respondents to be marketing tricks urging them to make larger purchases. The correct interpretation and positive perception of the claims in this study also depended on whether they related to health benefits or nutritional values that were important to the participants. Another important finding of this work is that in several cases respondents over-interpreted the statements by assigning them meanings that they did not objectively indicate (Hodgkins, et al., 2019, pp. 7-24).

In another paper - a systematic review and meta-analysis of studies conducted in 2014-2017, the impact of food labeling on food purchases, consumer health and the activities of producers was examined. The overall conclusion of this paper is that food labeling has a beneficial effect on protecting the health of consumers. Food labels have been shown to reduce fat consumption and the overall energy value of the diet. In addition, they encourage more frequent consumption of vegetables. However, they still do not affect the consumption of salt, carbohydrates, protein, saturated fats, fruits or whole grains (Shangguan, et al., 2019, pp. 7-10).

However, there are also papers whose results indicate that claims induce consumers to consume excessively. This may be the case for individual nutrients when consumers mistakenly believe that the more they consume, the better for their health, or are unaware that they are already consuming the ingredient in excess. It also happens that statements are not precise, which leads them to be misunderstood. This is so, for example, in the case of the statement "provides energy", which only states that the product is not calorie-free (and often that it is high-calorie), but for some consumers this message may mean that the consumption of the product will have a stimulating effect on them (Chandon \& Wansink, 2012, pp. 8).

Misinterpretation is also common in the case of claims regarding the content of a particular nutrient. This is mainly the case when the consumer judges the product based on the claim itself without analyzing the nutrition 
table or ingredient list. This is a particularly harmful approach, as the claims only draw attention to healthy ingredients, thereby diverting it from those that are dangerous to health. The same is true when the claim concerns the reduction of the risk of disease by consuming a particular product, while this product at the same time contains ingredients that increase this risk. An equally important problem for consumers is the so-called "Halo effect", which in relation to products with claims refers to the phenomenon of attributing qualities to them that they do not have. However, there is no doubt that not only consumers are to blame, but also producers who are fully aware of the presence and operation of these mechanisms (Talati, et al., 2017, pp.2).

\section{Survey methodology - examining awareness and perception of claims among consumers}

In the period from 20.04.2021 to 04.05.2021, a questionnaire with elements of experimental measurement was carried out. The study used the CAWI method using Google's web forms. The selection of the sample was purposive and was performed using the "snowball sampling" method.

The sample consisted of 200 respondents of Polish nationality. The individual characteristics of the respondents are presented in Table 1.

In the initial questions in the survey, participants rated a food product presented to them in pictures, which contained various configurations of claims on their packaging. This section of the form was the only one that varied for individual participants. By sending the appropriate versions of the form, the respondents were divided into 4 groups of 50 people. Group 1 received a form with pictures of products bearing nutrition claims (NC), group 2 with health claims $(\mathrm{HC})$, group 3 with both types of claims (NHC), and group 4 with pictures of products without claims, as the control group (C). The other packaging elements of the products presented in the pictures for all groups were identical and did not contain any advertising slogans, trademarks or names of manufacturers. 


\section{Table 1. Individual characteristics of respondents}

\begin{tabular}{|c|c|c|c|c|}
\hline \multicolumn{5}{|c|}{ Sex } \\
\hline \multirow{2}{*}{\multicolumn{2}{|c|}{$\begin{array}{c}\text { Women } \\
73 \%\end{array}$}} & & \multirow{2}{*}{\multicolumn{2}{|c|}{$\begin{array}{l}\text { Men } \\
27 \%\end{array}$}} \\
\hline & & & & \\
\hline \multicolumn{5}{|c|}{ Age } \\
\hline $13-17$ & $18-24$ & & $25-39$ & $>40$ years old \\
\hline $3.50 \%$ & $54.50 \%$ & & $30 \%$ & $12 \%$ \\
\hline \multicolumn{5}{|c|}{ Education } \\
\hline \multirow{2}{*}{$\begin{array}{l}\text { Higher } \\
60.50 \%\end{array}$} & & \multirow{2}{*}{$\begin{array}{l}\text { Medium } \\
36.50 \%\end{array}$} & & \multirow{2}{*}{$\begin{array}{c}\text { Basic } \\
3 \%\end{array}$} \\
\hline & & & & \\
\hline \multicolumn{5}{|c|}{ Financial status } \\
\hline Very good & \multirow{2}{*}{$\begin{array}{l}\text { Good } \\
52.00 \%\end{array}$} & \multirow{2}{*}{$\begin{array}{l}\text { Average } \\
33.50 \%\end{array}$} & \multirow{2}{*}{$\begin{array}{c}\text { Bad } \\
3.50 \%\end{array}$} & Very bad \\
\hline $11.00 \%$ & & & & $0.00 \%$ \\
\hline \multicolumn{5}{|c|}{ Subjective assessment of health } \\
\hline Very good & \multirow{2}{*}{$\begin{array}{l}\text { Good } \\
52.00 \%\end{array}$} & \multirow{2}{*}{$\begin{array}{l}\text { Average } \\
26.50 \%\end{array}$} & \multirow{2}{*}{$\begin{array}{c}\mathrm{Bad} \\
5.50 \%\end{array}$} & Very bad \\
\hline $15.50 \%$ & & & & $0.50 \%$ \\
\hline \multicolumn{5}{|c|}{ Subjective assessment of diet } \\
\hline Very healthy & \multirow{2}{*}{$\begin{array}{c}\text { Rather healthy } \\
46 \%\end{array}$} & \multirow{2}{*}{$\begin{array}{c}\text { Average } \\
32.50 \%\end{array}$} & \multirow{2}{*}{$\begin{array}{c}\text { Rather unhealthy } \\
12 \%\end{array}$} & Very unhealthy \\
\hline $9 \%$ & & & & $0.50 \%$ \\
\hline \multicolumn{5}{|c|}{ Subjective assessment of knowledge about healthy eating } \\
\hline Very large & Rather large & Average & Rather small & Very small \\
\hline $5 \%$ & $32 \%$ & $49.50 \%$ & $11 \%$ & $2.50 \%$ \\
\hline
\end{tabular}

\section{Figure 1. Example of a product picture used}

\section{in Part A of a research questionnaire}

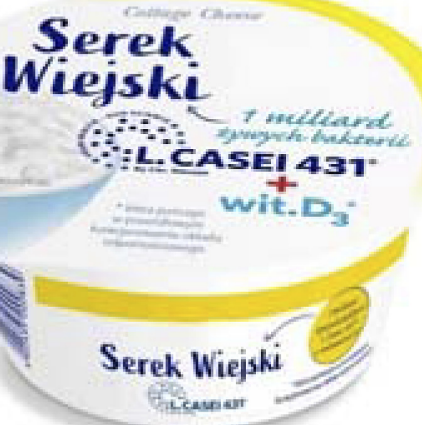


The evaluation criteria were:

- Health;

- Caloric value;

- Taste;

- The reliability of the information on the label;

- Willingness to purchase;

- Willingness to consume.

The rating scale was from 1 to 5 . The ratings in each group were added up and then the average was drawn from them.

The next questions concerned the degree of interest in healthy eating and the information on food labels, as well as the level of respondents' practical and theoretical knowledge about claims. This made it possible to explore the standard of knowledge concerning food law among the respondents, as well as to discover how this translates into the ability to interpret claims.

The study also examined the interpretation of claims as separate messages not appearing on a specific product. Participants were asked to choose answers in the form of sentences that most accurately describe their feelings about a specific health or nutrition claim presented to them. For statements, any number of responses could be selected from:

1) It is worth buying this product;

2) The information is reliable for me;

3) The information is understandable to me;

4) This product is healthy;

5) This product does not taste good;

6) The information encourages the consumption of the product.

The survey form was completed by collecting basic data on respondents, such as age, education, financial situation and health status, which are of great importance for making food choices and purchasing decisions.

To ensure the reliability of the results, the collected data were subjected to statistical tests. Statistical analysis was based, inter alia, on the Pearson correlation test or Student's t test for two averages. 


\section{Results}

The findings of the study are listed in the Tables and Charts below. The differences in the assessment of the products depending on the claims made on them were statistically insignificant. However, for some products, the impact of the claims on the participants' product assessment was particularly evident:

\section{Table 2. The highest and lowest product ratings given, by group of consumers}

\begin{tabular}{l|c|c|c|c}
\hline Assessment criterion & Lowest Rating & Product & Highest Rating & Product \\
\hline Healthiness & C & Chocolate bar & NHC & Cottage cheese \\
\hline Calorific value & NHC & Cottage cheese & C & Chocolate bar \\
\hline Taste & & Salt & Fruit juice \\
\hline $\begin{array}{l}\text { Reliability of the information } \\
\text { contained on the label }\end{array}$ & HC & Chocolate bar & NHC & Oatmeal \\
\hline $\begin{array}{l}\text { Willingness to purchase } \\
\text { Desire to consume }\end{array}$ & & & & \\
\hline
\end{tabular}

Legend:

HC - Group presented with only health claims

NHC - Group presented with nutrition and health claims

C - Group presented with no claims (Control)

(For the group presented with only nutrition claims, NC, neither lowest nor highest ratings were recorded.)

$83 \%$ of the sample rated their level of interest in healthy eating as medium and $20 \%$ as very high. The most important information for the respondents on food labels turned out to be: use-by date, the price of the product and nutrition information on the back of the packaging, such as the nutrition table or composition. Right behind them were: markings and information contained on the front of the pack.

$29 \%$ of respondents stated they always pay attention to the detailed information presented on the packaging of food products, $41 \%$ that they do so usually, while only $4 \%$ that they never do so.

Slightly more than half of the participants could not point out the difference between a nutrition claim and a health claim, while the vast majority did not know what the real meaning of individual nutrition claims was. 


\section{Chart 1. Knowledge of statements among respondents}

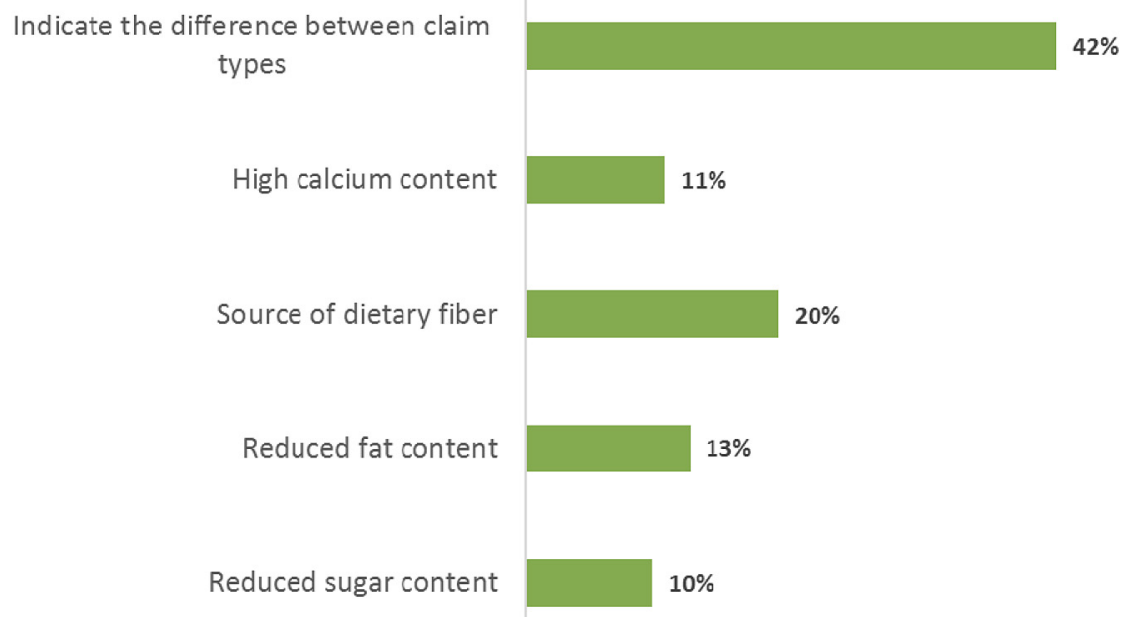

It was also noted that respondents were skeptical of health-related information on food packaging. 36\%, which is the largest proportion, believed that placing such information on the label is regulated by law, but the rules are often violated by manufacturers.

Statements presented as separate messages were most often associated by respondents with a healthy product, and the least often indicated to them that the product does not taste good.

Table 3. The meaning of the selected statements in the opinion of the respondents

\begin{tabular}{l|l|l}
\hline \multicolumn{1}{c|}{ Statement } & \multicolumn{1}{c|}{ Most selected } & \multicolumn{1}{c}{ Least selected } \\
\hline Natural & $\begin{array}{l}\text { Information encourages the consumption } \\
\text { of the product }\end{array}$ & $\begin{array}{l}\text { This product does not taste } \\
\text { good }\end{array}$ \\
\hline $\begin{array}{l}\text { Source of dietary fiber } \\
\text { This product is healthy } \\
\text { bowel function }\end{array}$ & $\begin{array}{l}\text { The information is understandable } \\
\text { to me }\end{array}$ & \\
\hline $\begin{array}{l}\text { Source of omega-3 fatty acids } \\
\text { Docosahexaenoic acid(DHA) } \\
\text { contributes to the maintenance } \\
\text { of normalfunction of the brain }\end{array}$ & $\begin{array}{l}\text { This product is healthy } \\
\text { to me information is understandable }\end{array}$ & \\
\hline \begin{tabular}{l} 
High content of vitamin D \\
\hline
\end{tabular} & This product is healthy & \\
\hline
\end{tabular}




\section{Conclusions}

The results of this study show that the impact of the claim on the perception of the health benefits of the product by consumers is strongly dependent on the specific product being assessed. The credibility and significance of the statement for the consumer may be limited by their previous prejudices. Therefore, the inclusion of a claim on a product should be preceded by promotional activities aimed at increasing the perception of its attractiveness by consumers.

The study also showed that the presence of claims affects the deterioration of the perception of the palatability of products considered to be the least healthy.

A significant percentage of the respondents declared that when shopping they pay attention not only to the front of the product packaging, but also to the back. Taking into account the fact that nutrition claims are usually found on the front of the packaging, while health claims on the back, it can be concluded that using both types of claims on labels may be more effective in promoting health than using only one type. Furthermore, based on the results of this work, it can be concluded that consumers now clearly expect information on labels detailing the health effects of a nutrient, so using nutrition claims alone will become increasingly unsatisfactory for them.

Consumers are actually more likely to analyze food labels. This is an important result for food producers, which suggests that they should pay particular attention to the appropriateness of the information provided on the product packaging. Clarifying the content of labels for a thorough analysis may be related to another phenomenon that has been demonstrated in this paper, namely that consumers show a low level of confidence in the credibility of statements. The study did not show that consumer distrust of the credibility of claims was correlated with low levels of knowledge about them.

Based on the respondents' answers, it cannot be concluded that the presence of the claims meant that the product was seen as less caloric. It seems, therefore, that consumers' awareness of the processes of maintaining and achieving a healthy body weight has increased significantly. However, it is important that participants reported a relatively high level of knowledge of healthy eating in this study. 
Another conclusion is that greater interest in healthy eating does not translate into the ability to correctly interpret statements. The respondents had severe problems in indicating what specific and actually existing health and nutrition claims mean. Therefore, it can be concluded that educating consumers on healthy eating does not increase their ability to use claims and solutions are needed to help raise public awareness of the legal aspects of food labeling.

\section{Limitations and future research}

Only Polish food consumers took part in the study, most of whom were healthy women with higher education and declaring a good financial situation. The majority of respondents declared a high level of interest in healthy eating, as well as rating the quality of their diet as good or average. Therefore, the results may have been significantly different if the survey had been conducted on respondents with other individual characteristics. Moreover, it also unclear how the results of this study translate into food purchases in real-world shop conditions. There is a need for research involving larger and more diverse groups of consumers that reflect the real circumstances of food shopping to a greater extent.

\section{References}

1. Annunziata, A., \& Mariani, A. (2019). Do Consumers Care about Nutrition and Health Claims? Some Evidence from Italy. Nutrients, 11(11), 2735. https://doi.org/ 10.3390/nu11112735

2. Chandon, P., \& Wansink, B.(2012). Does food marketing need to make us fat? A review and solutions. Nutrition Reviews, 70(10), 571-593. https://doi.org/10.1111/j.17534887.2012.00518.x

3. Davidović, D., Paunović, K., Zarić, D., Jovanović, A., Vasiljević, N., Stošović, D., \& Tomanić, M. (2021). Nutrition and Health Claims Spectra of Pre-Packaged Foods on Serbian Supermarket Shelves: A Repeated Cross-Sectional Study. Nutrients, 13(8), 2832. doi:10.3390/nu13082832

4. De Boer, A. (2021). Fifteen Years of Regulating Nutrition and Health Claims in Europe: The Past, the Present and the Future. Nutrients, 13(5), 1725. doi:10.3390/nu13051725 
5. Hodgkins, C., E., Egan, B., Peacock, M., Klepacz, N., Miklavec, K., Pravst, I., ... Raats, M., M. (2019). Understanding How Consumers Categorise Health Related Claims on Foods: A Consumer-Derived Typology of Health-Related Claims. Nutrients, 11(3), 539. https://doi.org/10.3390/nu11030539

6. Lorenzoni, G., Minto, C., Temporin, M., Fusca, E., Bolzon, A., Piras, G., ... Gregori, D. (2019). (Ab)use of Health Claims in Websites: The Case of Italian Bottled Waters. International Journal of Environmental Research and Public Health, 16(17), 3077. doi:10.3390/ijerph16173077

7. Lynam, A., McKevitt, A., \& Gibney, M. (2011). Irish consumers' use and perception of nutrition and health claims. Public Health Nutrition, 14(12), 2213-2219. doi:10.1017/S1368980011000723

8. Oostenbach, L. H., Slits, E., Robinson, E., \& Sacks, G. (2019). Systematic review of the impact of nutrition claims related to fat, sugar and energy content on food choices and energy intake. BMC Public Health, 19(1), 1296. https://doi.org/10.1186/s12889-019-7622-3

9. Regulation (EC) No 107/2008 of the European Parliament and of the Council of 15 January 2008 amending Regulation (EC) No 1924/2006 on nutrition and health claims made on foods as regards the implementing powers conferred on the Commission. h t t p s:// e u r - lex.europa.eu/legal-content/E N/TX T/ H T M L/ ?uri=CELEX:32008R0107\&from $=\mathrm{EN}$

10. Regulation (EC) No 1924/2006 of the European Parliament and of the Council of 20 December 2006 on nutrition and health claims made on foods. https:/eurlex.europa.eu/legal-content/EN/TXT/HTML/?uri=CELEX:32006R1924\&from=en

11. Shangguan, S., Afshin, A., Shulkin, M., Ma, W., Marsden, D., Smith, J., ... Food PRICE (Policy Review and Intervention Cost-Effectiveness) Project (2019). A Meta-Analysis of Food Labeling Effects on Consumer Diet Behaviors and Industry Practices. American Journal of Preventive Medicine, 56(2), 300-314. https://doi.org/10.1016/ j.amepre.2018.09.024

12. Steinhauser, J., \& Hamm, U. (2018). Consumer and product-specific characteristics influencing the effect of nutrition, health and risk reduction claims on preferences and purchase behavior - A systematic review. Appetite, 127, 303-323. doi: 10.1016/ j.appet.2018.05.012.

13. Steinhauser, J., Janssen, M., \& Hamm, U. (2019). Who Buys Products with Nutrition and Health Claims? A Purchase Simulation with Eye Tracking on the Influence of Consumers' Nutrition Knowledge and Health Motivation. Nutrients, 11(9), 2199. https://doi.org/10.3390/nu11092199

14. Szymecka-Wesołowska, A. (2011). Regulacja oświadczeń żywieniowych i zdrowotnych w Stanach Zjednoczonych [Regulation of Nutrition and Health Claims in the United States]. Przeglad Prawa Rolnego 2(9). Accessed from: https://repozytorium.amu.edu.pl/ bitstream/10593/2326/1/AGNIESZKA_SZYMECKA-WESOLOWSKA_199-223.pdf

15. Szymura, M. (2012). Oświadczenia żywieniowe i zdrowotne - aspekty prawne [Nutrition and Health Claims - Legal Aspects]. Logistyka, 4(2), 1308-1314. Accessed from https://www.logistyka.net.pl/bank-wiedzy/item/download/78499_1119627c77618e $158 \mathrm{a} 60 \mathrm{e} 3 \mathrm{ca} 3 \mathrm{ceef} 5 \mathrm{f5}$ 
16. Talati, Z., Pettigrew, S., Neal, B., Dixon, H., Hughes, C., Kelly, B., \& Miller, C. (2017). Consumers' responses to health claims in the context of other on-pack nutrition information: a systematic review. Nutrition Reviews, 75(4), 260-273. https://doi.org/10.1093/nutrit/nuw070

Sylwia Majcher, MA — She holds a master's degree from the Poznań University of Economics and Business in the field of management with a specialization in trade and marketing. Interests: marketing of food products, dietetics, consumer protection, consumer ethics in the food market, organic food. 